\title{
THE EFFICACY OF LASER THERAPY AND IBUPROFEN ON PAIN AFTER ELASTOMERIC SEPARATOR PLACEMENT: RAPID REVIEW
}

\author{
Regina Yosephine Simarmata***, Ida Ayu Evangelina**, Avi Laviana**, Endah Mardiati** \\ * Orthodontic Resident, Faculty of Dentistry, Padjadjaran University \\ ** Orthodontic Department, Faculty of Dentistry, Padjadjaran University \\ Correspondence : regina.yosephine@unpad.ac.id
}

\section{Keywords:}

elastomeric separator, ibuprofen, laser therapy, pain management

\section{ABSTRACT}

Background: Separator placement is the first step in orthodontic treatment, which aims to create space between teeth before molar band placement. This procedure can cause pain for the patient. Pain management after separator placement can be done through pharmacological and non-pharmacological approaches.

Method: The aim of this rapid review was to determine the efficacy of laser therapy and ibuprofen for pain management after elastomeric separator placement in orthodontic treatment.

Result: Ten articles were included in this review, four articles gave laser therapy interventions and six articles gave ibuprofen therapy interventions. The result of the quality assessment using Strength of Recommendation Taxonomy (SORT) was laser therapy intervention has one good quality articles and three limited-quality articles, while ibuprofen therapy has two good quality articles and four limited-quality articles.

Conclusion: The efficacy of laser therapy and the efficacy of ibuprofen on pain after separator placement is good, with the strength of the clinical recommendation of ibuprofen is better than laser therapy.

\section{INTRODUCTION}

Separators are used to create space for placement of band that later anchors the fixed orthodontic appliance. ${ }^{1}$ The use of elastic separators is widely spread in orthodontic treatment, not only for their convenience in handling, but also due to storage, and produced significantly more space compared to the spring separators. ${ }^{1,2}$

Placement of separator induces pain in patients. Pain usually begins at 4 hours after separator placement, increases to a peak level at 24 hours, remains bother for the next 3 days, and diminishes over the next 6-8 days. The pain experienced is due to the constant pressure, ischemia, inflammation, and edema in the periodontal ligaments of the teeth that are moved during orthodontic movements. ${ }^{1,3-5}$

Pain is a subjective response which shows large individual variation. It is affected by some factors such as age, gender, individual pain threshold, magnitude of force applied, present emotional state and stress, cultural differences and previous pain experiences. ${ }^{3,6-9}$ Pain due to orthodontic treatment is defined as a moderate level of pain and a tolerable mild-to-moderate jaw discomfort. ${ }^{10}$ Pain has been the prime reason for discontinuation of orthodontic treatment. ${ }^{1,10}$

Several methods have been invented to alleviate orthodontic pain in clinical practice, 
including pharmacological approaches, mechanical approaches, laser irradiation therapy and behavioural approaches. ${ }^{11,12}$ Ibuprofen is a nonsteroidal anti-inflammatory drug that has antinociception, anti-inflammatory, and antipyretic effects. It acts as a non-selective inhibitor of the cyclo-oxygenase 1 (COX-1) and COX-2. ${ }^{13}$ Ibuprofen is significantly effective in reducing pain..$^{513-15}$ Laser, a highly popular technological application in recent times, is also being used as an alternative to reduce pain without affecting tooth movement. ${ }^{8,16}$ Laser is thought to control pain by hyperpolarization of the nerve cell membrane, which increases the patient's pain threshold. ${ }^{16}$

The aim of this rapid review was to determine the efficacy of laser therapy and ibuprofen for pain management after elastomeric separator placement in orthodontic treatment.

\section{LITERATURE REVIEW}

The eligibility criteria were used in the selection of the articles:

Population: patients who used elastomeric separators in orthodontic treatment.

Intervention: article containing administration of laser therapy or ibuprofen to control pain after elastomeric separator placement.

Comparison: article containing administration of placebo or no treatment after elastomeric separator placement.

Outcome: efficacy of laser therapy and ibuprofen in reducing the pain scale based on the VAS score.

Specific search strategies per database were used to identify relevant articles using the AND and OR boolean operators and the limit function of each database if available. The search was carried out using keywords: VAS, pain, orthodontic, and separator by MeSH.

The inclusion criteria were articles in English and in Indonesian, articles containing clinical trials of administration of ibuprofen for pain management after elastomeric separator placement, articles containing clinical trial of laser therapy for pain management after elastomeric separator placement, and accessible full-text articles. The exclusion criteria were non-human trial articles, split-mouth design, absence of a control group, thesis, dissertation, scientific papers, and research that did not use VAS to measure pain.

The present review was done according to the Preferred Reporting Items for Systematic Review and Meta-Analysis (PRISMA) guidelines. A total of 361 articles were identified through a database search (PubMed $=48$ articles, Google Scholar $=216$ articles, ScienceDirect $=36$ articles, Science.gov $=25$ articles, Cochrane Library $=8$ articles, and The Angle Orthodontist $=28$ articles). The identified articles were exported to the Mendeley Desktop application (version 1.19.4) ${ }^{17}$ to remove duplicates, and a total of 243 articles remained after the duplicates were removed. A total of 230 articles were excluded because they were irrelevant based on the title and abstract, while the other 13 articles were included in a full-text evaluation. A total of 10 articles met the eligibility criteria and were included in the review, the remaining 3 articles were excluded because 2 articles were split-mouth design and 1 article was an ongoing study. The flow diagram of the study selection process is presented in Figure 1. 


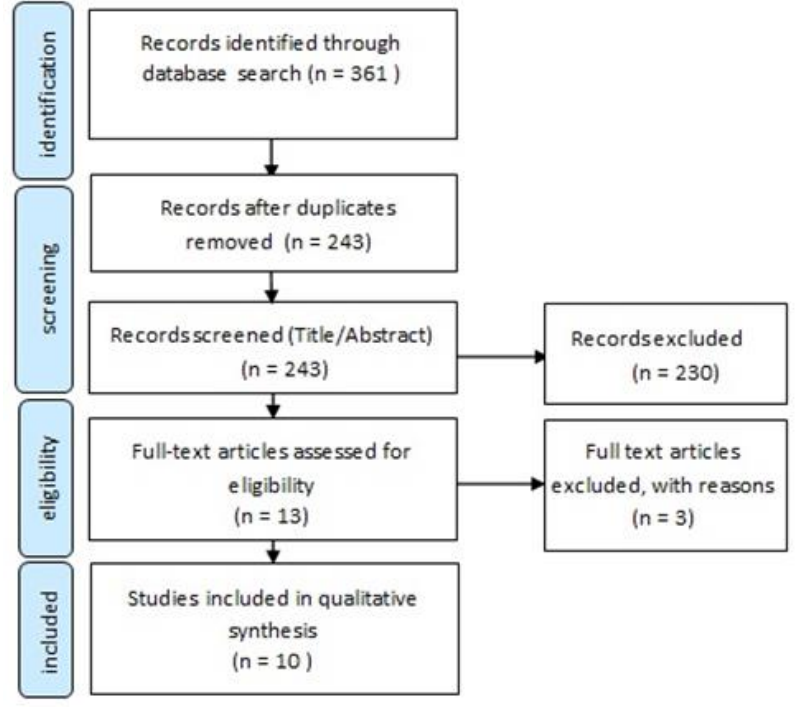

Figure 1. PRISMA Flow Diagram of The Study Selection Process

All included articles were a randomised control trial design, 3 articles $^{18-20}$ were a parallel study design, 3 articles ${ }^{19,21,22}$ were a prospective design, 1 article ${ }^{23}$ was a retrospective design, and 1 article $^{24}$ was a preliminary clinical study design. In total, 773 participants were included. A total of 4 included articles ${ }^{23-26}$ comprised low level laser therapy interventions, while 6 articles ${ }^{18-22,27}$ comprised ibuprofen interventions. One included article $^{26}$ reported laser irradiation was significantly effective in reducing pain compared to the placebo group. Three included articles ${ }^{23-25}$ reported laser irradiation was significantly effective in reducing pain compared to the untreated control group, but 2 of them ${ }^{24,25}$ reported that there was no significant difference in pain in the laser group compared to the placebo group. Six articles ${ }^{18-22,27}$ reported ibuprofen was significantly effective in reducing pain compared to the placebo group. The characteristics of the included studies is presented in Table 1.

The risk of subjectivity of the included studies was made according to Cochrane Risk of Bias Tools for randomized control trial is presented in Figure 2.

Table 1. The characteristics of the included studies

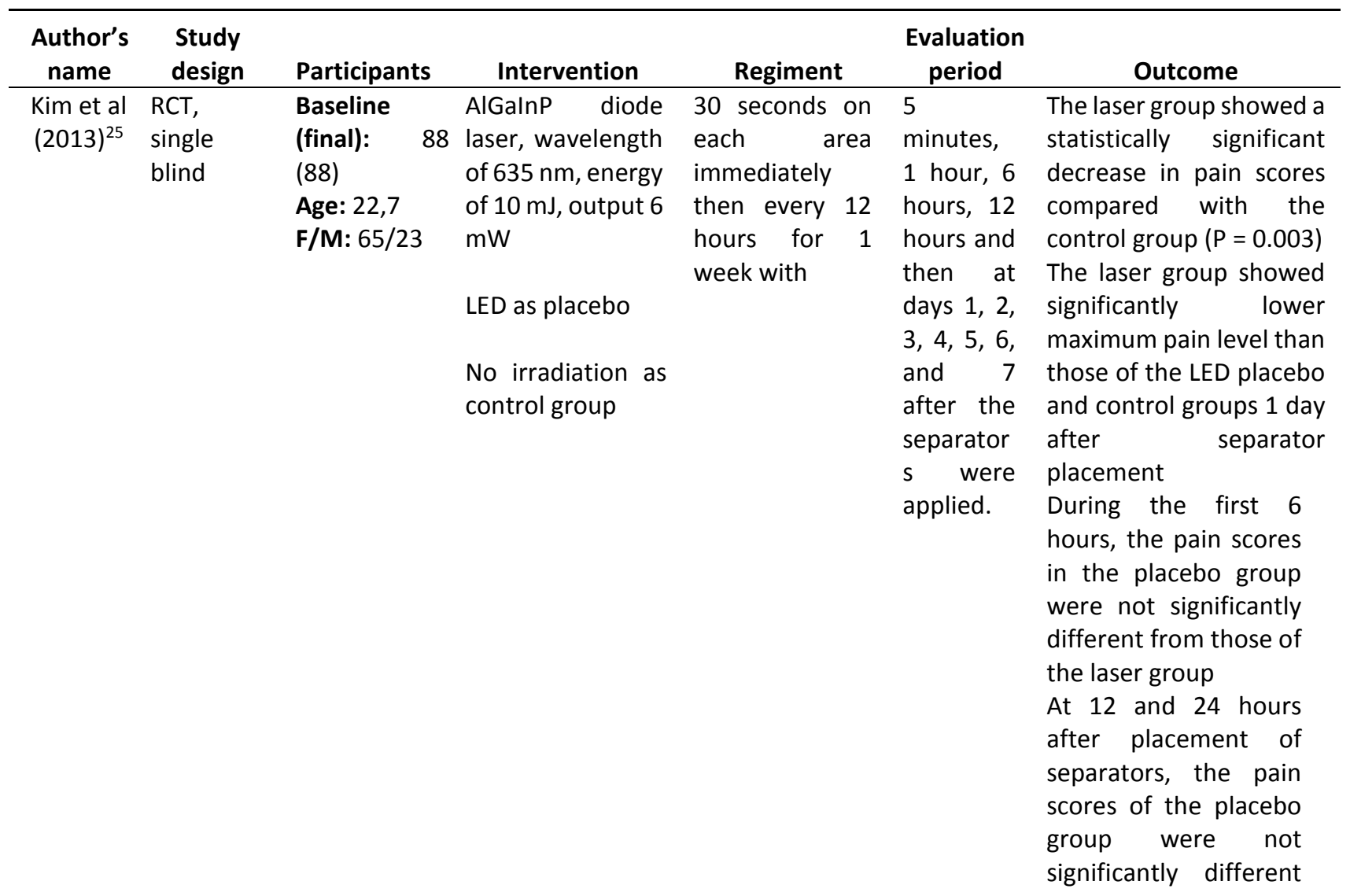


from those of the

control group.

$\begin{array}{clll}\begin{array}{c}\text { Nobrega } \\ \text { et al }\end{array} & \begin{array}{l}\text { RCT, } \\ \text { double- }\end{array} & \begin{array}{l}\text { Baseline } \\ \text { (final):60(60) }\end{array} & \text { AlGalAr laser, 830 nm } \\ (2013)^{26} & \text { blind } & \text { Age: 12-26 } & \\ & & \text { years } & \text { Placebo } \\ & & \text { F/M:? }\end{array}$

25 sec per each 2, 6, and 24 There were significant $1 \mathrm{~J} / \mathrm{cm} 2$ hours and 3 differences in mean aplication along and 5 days pain scores between the root axis on after the two groups favoring the buccal side, orthodonti the group that received with three spot c separator LLLT in all measures, for placement, both spontaneous and in in occlusion pain, situations except on day 5 of relaxed and occluded mouth

Stein et al Retrospekt Baseline Diodelaser,660nm, 20 seconds every day Pain level significantly $(2015)^{23}$ if, (final): 40 output power applied to the before $\quad(p<0.05)$ lower in the LLLT Randomize (40) $100 \mathrm{~mW}$ separated teeth bedtime, group than in the control d fashion Age: 6-9 at the root level (day 1-5) study years No irradiation as perpendicular to F/M: 19/21 control group the alveolar group on day 1 There were no significant ridge in the demonstrable on days 2-5 mesial interproximal

space, both distal interproximal spaces, and directly in the root centers

\begin{tabular}{|c|c|c|c|c|c|c|}
\hline $\begin{array}{l}\text { Esper et al } \\
(2011)^{24}\end{array}$ & $\begin{array}{l}\text { Preliminary } \\
\text { clinical } \\
\text { study }\end{array}$ & $\begin{array}{l}\text { Baseline } \\
\text { (final):55 (52) } \\
\text { Age: } 24,1 \pm 8,1 \\
\text { years } \\
\text { F/M: } 16 / 39\end{array}$ & $\begin{array}{l}\text { LED GaAIAs } 640 \mathrm{~nm} \text {, } \\
0,10 \mathrm{~W}, 70 \text { detik } \\
\text { Placebo group } \\
\text { No irradiation as } \\
\text { control group }\end{array}$ & $\begin{array}{l}\text { touching the } \\
\text { gum } \\
\text { perpendicularly } \\
\text { on two points of } \\
\text { the vestibular } \\
\text { side and on the } \\
\text { lingual side of } \\
\text { the separated } \\
\text { molars, both } \\
\text { points were in } \\
\text { the cervical and } \\
\text { radicular region. }\end{array}$ & $\begin{array}{l}2,24,48, \\
72,96, \text { and } \\
120 \mathrm{~h} \text { after } \\
\text { therapy }\end{array}$ & $\begin{array}{l}\text { A lowering in the pain } \\
\text { sensitivity in the laser } \\
\text { group could be observed } \\
\text { when compared to the } \\
\text { control group, however, } \\
\text { there was no statistical } \\
\text { significance between the } \\
\text { groups during the 120-h } \\
\text { study period. } \\
\text { The placebo group was } \\
\text { statistically significant } \\
\text { compared to the laser } \\
\text { group only } 2 \text { h after the } \\
\text { orthodontic procedure } \\
\text { and the placebo group had } \\
\text { a lower sensitivity than } \\
\text { the laser group. }\end{array}$ \\
\hline
\end{tabular}




\begin{tabular}{|c|c|c|c|c|}
\hline \multirow[t]{2}{*}{$\begin{array}{l}\text { Nik et al } \\
(2016)^{27}\end{array}$} & $\begin{array}{l}\text { RCT, triple } \\
\text { blind }\end{array}$ & $\begin{array}{l}\text { Baseline } \\
\text { (final): } \\
(89)\end{array}$ & 101 & $\begin{array}{l}\text { acetaminophen } \\
650 \mathrm{mg} \text {, }\end{array}$ \\
\hline & & $\begin{array}{l}\text { Age: } \\
\text { years }\end{array}$ & 15,6 & $\begin{array}{l}\text { liquified ibuprofen } \\
400 \mathrm{mg}\end{array}$ \\
\hline
\end{tabular}

Placebo

$\begin{array}{llll}\text { Law et al } & \text { RCT } & \text { Baseline } & \text { ibuprofen } 400 \mathrm{~m} \\ (2000)^{21} & \text { prospectiv } & \text { (final): } 66 & \\ & \text { e study, } & \text { (63) } & \text { placebo } \\ & \text { double } & \text { Age: 13 years } & \\ \text { blind } & \text { F/M: 38/25 }\end{array}$

Shetty et RCT al $(2013)^{18}$ paralel, double blind
Baseline Piroxicam $20 \mathrm{mg}$

(final):68 (68)

Age: 18 years Ibuprofen $400 \mathrm{mg}$ F/M: $45 / 23$ one hour before immediatel The mean pain scores in separator y after acetaminophen group and placement and separator liquefied ibuprofen group every six hours placement, were significantly lower afterward (five 2 hours, 6 than the placebo group doses in total) hours, at bedtime, and 24 hours after separator placement

(1) ibuprofen 2, 6, and 24 Subjects who had taken taken orally 1 hours, as ibuprofen before their hour before well as at 2, appointment reported separator 3 , and 7 significantly decreased placement and a days after levels of pain (9.5 \pm 11.6 ; lactose placebo separator mean \pm SD) when taken orally placement compared with subjects immediately during who had taken after the chewing, preoperative placebo and appointment biting, postoperative ibuprofen (2) a lactose fitting back $(20.9 \pm 21.7)$ or the placebo taken teeth placebo medication both orally 1 hour together, preoperatively and before fitting front postoperatively (25.2 \pm separator teeth 27.8).

placement and There was no significant ibuprofen taken difference in pain levels orally immediately after the appointment

(3) a lactose placebo taken orally 1 hour before separator placement and again immediately after the appointment.

one hour prior to 2 hours, 4 piroxicam and ibuprofen separator hours, 6 group significantly placement, 3 hours, showed less pain level hours and 7 hours bedtime, $\quad(P<0,05)$ compared to after separator on those on the placebo placement. awakening group at 2 hours and 6 the hours evaluation during following bitting

day and 24 piroxicam and ibuprofen hours after group significantly administrat showed less pain level ion during $(P<0,05)$ compared to when those on the placebo biting, group at 2 hours, 6 hours , 
Kohli et al Prospectiv Baseline $(2011)^{19}$ e study, (final): 90 $\begin{array}{ll}\text { parallel- } & (90) \\ \text { arm, } & \text { Age: } 13 \text { years }\end{array}$ double 9 months -18 Placebo blind years 2 months

F/M: $45 / 45$

chewing, bedtime during fitting fitting front anterior teeth together teeth piroxicam and ibuprofen together, group showed less pain and fitting level compared to those back teeth on the placebo group at 2 together hours and 6 hours during fitting posterior teeth together, significance not stated.

ibuprofen $400 \mathrm{mg}, 1$ hour before 2 hours, 6 The ibuprofen and separator hours, piroxicam groups had piroxicam $20 \mathrm{mg}$, placement nighttime significantly lower pain on the day level $(P<0.05)$ compared of $\quad$ to the placebo group at 2 appointme hours and 6 hours after nt, 24 separator placement hours after during biting

the The ibuprofen and appointme piroxicam groups had $\mathrm{nt}$, and 2 significantly lower pain days, 3 perceptions $(P<0.05)$ days, and 7 compared to the placebo days after group at 2 hours, 6 hours, separator and night time during placement fitting front teeth

during, The ibuprofen and chewing, piroxicam groups had biting, lower pain perceptions fitting front compared to the placebo teeth, and group at the $2 \mathrm{~h}$ and $6 \mathrm{~h}$ fitting back during fitting posterior teeth teeth, significance not stated.

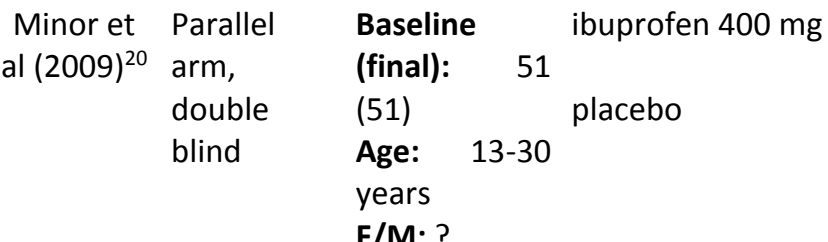

one hour prior Immediatel The group that received to separator $\mathrm{y}$ after, 2 preemptive and placement, 3 hours, 6 posttreatment ibuprofen hours and 7 hours, (group A) experienced less hours after bedtime, pain at 2 hours compared separator on to the group that took placement awakening, ibuprofen only after and 24 separator placement (B) hours after and the placebo group (C), separator but did not statistically placement significant.

during The group that received biting, preemptive and chewing, posttreatment ibuprofen fitting front (group A) experienced teeth to- significantly less pain at 6 gether, and hours and at bedtime on fitting back the night of separator teeth placement.

together Group A also reported less pain on the morning after 


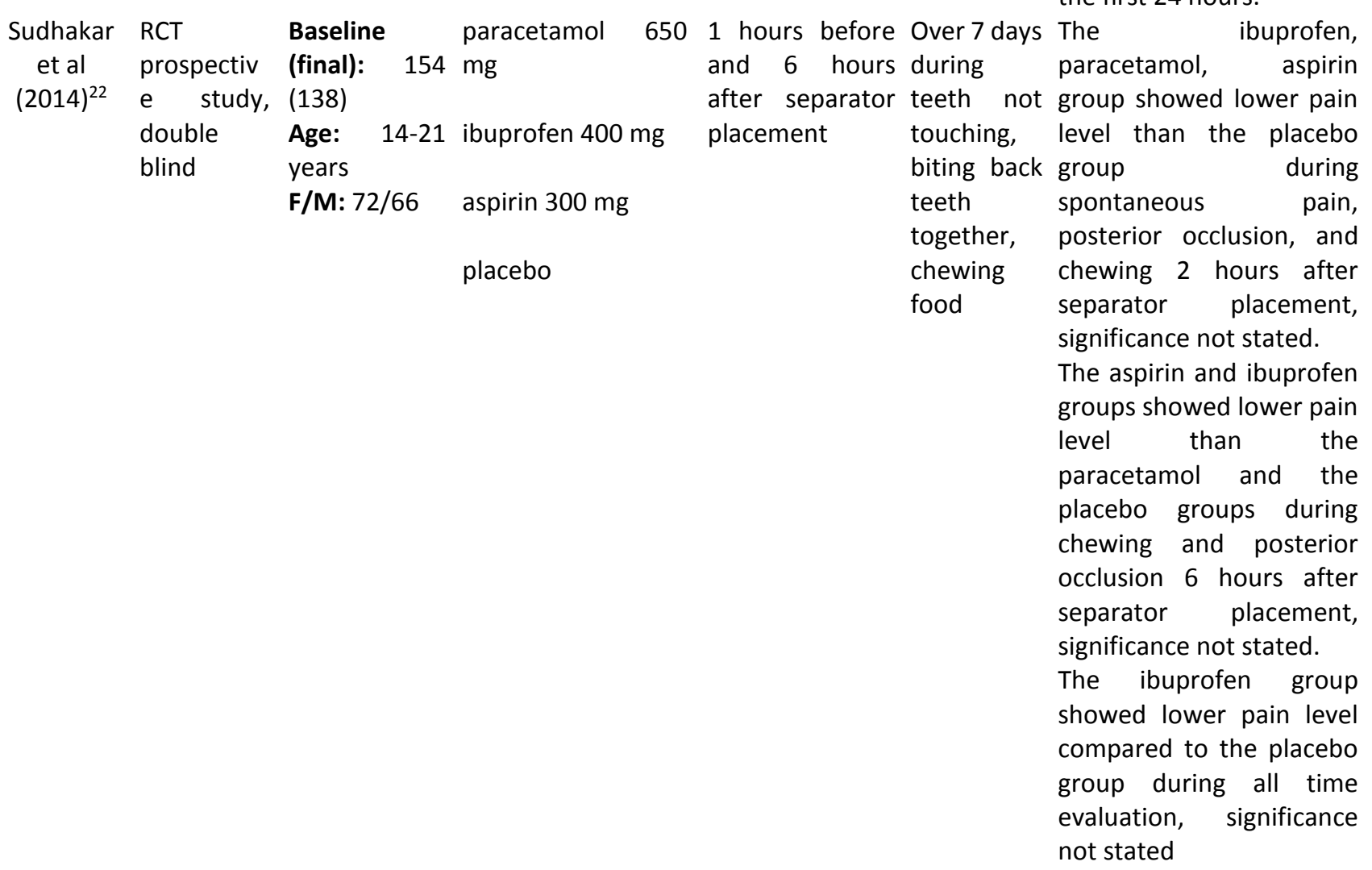

\begin{tabular}{|c|c|c|c|c|c|c|c|c|c|c|}
\hline 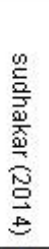 & 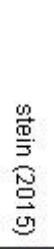 & 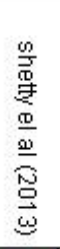 & 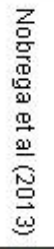 & 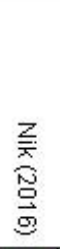 & 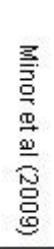 & 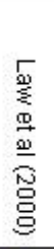 & 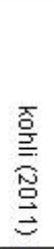 & 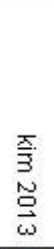 & 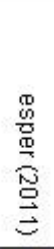 & \\
\hline$\sim$ & $\omega$ & $\odot$ & $\hookrightarrow$ & $\odot$ & $\sim$ & $\sim$ & $\sim$ & $\omega$ & $\sim$ & Random sequence generation (selection bias) \\
\hline$\sim$ & $\sim$ & $\odot$ & $\odot$ & $\odot$ & $\sim$ & $\odot$ & $\odot$ & $\sim$ & $\cdot v$ & Allocation concealment (selection bias) \\
\hline$\odot$ & $\sim$ & $\odot$ & $\odot$ & $\odot$ & $\odot$ & $\odot$ & $\odot$ & (1) & $\sim$ & Blinding of participants and personnel (performance bias) \\
\hline$\odot$ & $\cdot$ & $\odot$ & $\odot$ & $\odot$ & $\odot$ & $\odot$ & $\sim$ & (1) & $\cdot$ & Blinding of outcome assessment (detection bias) \\
\hline$\odot$ & $\odot$ & $\odot$ & $\odot$ & $\odot$ & $\odot$ & $\odot$ & $\odot$ & $\odot$ & $\odot$ & Incomplete outcome data (attrition bias) \\
\hline$\sim$ & $\cdot$ & $\sim$ & $\sim$ & $\sim$ & $\cdot v$ & (1) & $\sim$ & $\sim$ & $\sim$ & Selective reporting (reporting bias) \\
\hline$\odot$ & $\odot$ & $\odot$ & $\odot$ & $\odot$ & $\odot$ & $\odot$ & $\odot$ & $\odot$ & $\sim$ & Other bias \\
\hline
\end{tabular}


Figure 2 The risk of subjectivity of the included studies ${ }^{[28]}$ Iow risk, $\bullet$ high risk, 3 unclear risk

\section{DISCUSSION}

The heterogeneity of study designs such as differences in intervention components, study evaluation periods, comparison groups, and differences in the inclusion and exclusion criteria included in each article may lead to finding different results between studies. One article ${ }^{23}$ included subjects aged 6-9 years with a mixed dentition period. Children's pain is very different from that which is experienced in adults. Different emotional and psychological factors can affect the children's pain comprehension and stimulate their response. Another difference is the nociceptive system, the number of nociceptors and neuromediators is higher in children, meaning a higher sensitivity to pain in childhood The number of nociceptors and neuromediators is higher in children, meaning a higher sensitivity to pain in childhood. 29

Optimal penetration of lasers in humans seems to be in the range $690 \mathrm{~nm}$ and $860 \mathrm{~nm} .{ }^{30}$ Lasers in a range of $400 \mathrm{~nm}-700 \mathrm{~nm}$ can penetrate tissue for about $8 \mathrm{~mm}$, whereas the infrared lasers have approximately $2-3 \mathrm{~cm}$ penetration depth. The receptors that produce orthodontic pain are located in deep areas, and thus the application of infrared wavelength is more suitable for pain management. ${ }^{31}$

The insignificant differences between laser and placebo group might be the result of placebo effect, such as emotional modulation and subjective stress reduction during pain stimulation. ${ }^{25}$ The placebo effect can be defined as the improvement in the patient's symptoms after the administration of an inert substance in a context inducing positive expectations about its effects. ${ }^{32}$ The placebo effect was affected by expectations and closely related to emotional factors. ${ }^{33,34}$ The analgesic effect was obtained by suggestion through patient's expectations when taking a tablet that they believe was an analgesic. ${ }^{18}$

All articles containing ibuprofen for pain management after elastomeric separator placement gave it 1 hour prior to separator placement. Ibuprofen was rapidly and completely absorbed 1-2 hours after oral administration. ${ }^{35,36}$ The aim of analgesics administration before treatment was to block the afferent nerve impulses before they reach to the central nervous system. The body has enough time to absorb and distribute the drug before tissue damage and prostaglandin sequence production, and consequently would reduce inflammation reactions. ${ }^{13}$

All included articles mentioned that the pain after separator placement peaked after 24 hours. This result is consistent with other studies evaluating pain after elastomeric separator placement. 4,5,37-39 Separators compressed the periodontal ligament and induced inflammatory reactions. The pain peaked 24 hours after separator placement was associated with increased production of inflammatory mediators such as interleukin-1 $\beta \quad$ (IL-1 $\beta)$, substance $P, \quad$ and prostaglandin E2 at 24 hours after separator placement. ${ }^{37}$ Therefore, orthodontists should provide information to patients about pain and its management prior to separator placement.6,40-42

All included articles did not mention any side effects from the use of either laser therapy or ibuprofen. Ibuprofen was contraindicated in patients with gastrointestinal disorders, allergies, and can adversely affect orthodontic tooth movement. ${ }^{43}$ Ibuprofen inhibits prostaglandin production which was an important mediator of bone resorption 
contributing to orthodontic tooth movement. However, Alqahtani, et al in their study found that patients prescribed ibuprofen did not report any problem with tooth movement along with a significant reduction in pain after separator placement. $^{14}$ The use of lasers for pain management in orthodontics, to date, has had no negative side effects. ${ }^{44}$

Quality of evidence of the included study was assessed using Strength of Recommendation Taxonomy (SORT) show that 3 articles have good quality evidence (level 1) and 7 articles have limited quality evidence (level 2). The strength of recommendation for clinical practice of low level laser therapy is moderate (B) based on a 1 article with good quality evidence and 3 articles with limited quality evidence. The strength of recommendations for clinical practice of ibuprofen therapy is strong ( $A$ ) (based on 2 articles with good quality evidence and 4 articles with limited quality evidence.

Oshagh et al (2014) on their study compared the efficacy of ibuprofen and low level laser therapy on pain after separator placement concluded that laser therapy had no analgesic effect, whereas ibuprofen was most effective at 1 hour after administration. Laser therapy was a rather expensive treatment modality and harder to obtain, whereas ibuprofen seemed to be a cheaper, simpler and rather cost-effective treatment option. ${ }^{43}$ The use of an analgesic drug should only be adopted for patients with less tolerant of pain, meanwhile a single application of low level laser therapy does not seem to provide a fully effective protocol for this purpose..$^{45}$ Therefore, ibuprofen could be used for pain management after elastomeric separator placement. While, low-level laser therapy can be used as an alternative to non-pharmacological pain management in patients who have contraindications to the use of ibuprofen.

\section{CONCLUSION}

The efficacy of laser therapy and the efficacy of ibuprofen on pain after separator placement is good, with the strength of the clinical recommendation of ibuprofen is better than laser therapy.

\section{ACKNOWLEDGEMENT}

\section{CONFLICT OF INTEREST}

No conflict of interest

\section{REFERENCES}

1. Al-Balbeesi $\mathrm{H}$, Bin Huraib $\mathrm{S}$, Alnahas $\mathrm{N}$, Alkawari $\mathrm{H}$, Abu-Amara A, Vellappally $\mathrm{S}$, et al. Pain and distress induced by elastomeric and spring separators in patients undergoing orthodontic treatment. J Int Soc Prev Community Dent. 2016;6(6):549-53.

2. Mendes DF, Nascimento JE, Francisco A, Facholli DL, Casa MDA, Carvalho S, et al. Evaluation of plasticity and radiopacity of elastic separators by means of traction tests and radiography. Dental Press J Orthod. 2012;17(6):1-10.

3. Beck VJ, Farella M, Chandler NP, Kieser JA, Thomson WM. Factors associated with pain induced by orthodontic separators. J Oral Rehabil. 2014;41(4):282-8.

4. Goyal M, Khetwal D, Akshita, Amaan Ali S, Chawla R. Research article pain assessment after placing separators as well as initial archwire in orthodontic patients : A randomized clinical trial. Int J Curr Res. 2018;10(01):64631-4.

5. Aldrees A. Intensity of pain due to separators in adolescent orthodontic patients. J Orthod Sci. 2015;4(4):118.

6. Utomi IL, Odukoya OO. Pain and discomfort associated with orthodontic separator placement in patients attending the Lagos University Teaching Hospital, Lagos, Nigeria. Odontostomatol Trop. 2013;36(141):5-13.

7. Mahendra S, Reddy VP, M MC, Shetty B. Pain Control in Orthodontics-Causes and Management. Ann Essences Dent. 2011;3(3):102-6.

8. Kartal $\mathrm{Y}$, Polat-Ozsoy $\mathrm{O}$. Insight into orthodontic appliance induced pain: Mechanism, duration and management. World 
J Anesthesiol. 2016;5(1):28.

9. Marini I, Bartolucci ML, Bortolotti F, Innocenti G, Gatto MR, Alessandri Bonetti G. The effect of diode superpulsed low-level laser therapy on experimental orthodontic pain caused by elastomeric separators: a randomized controlled clinical trial. Lasers Med Sci. 2015;30(1):35-41.

10. Zealaiy A, Sokhairi S, Rhbeini A, Alsaud B, Batwa W, Alzain I, et al. Differences in SelfPerceived Pain and Jaw Discomfort Between Adult and Adolescent Orthodontic Patients. EC Dent Sci. 2018;17:2167-74.

11. Iwata K, Takeda M, Oh SB, Shinoda M. Neurophysiology of Orofacial Pain. In: Contemporary Oral Medicine [Internet]. Cham: Springer International Publishing; 2017. p. 123. Available from: http://link.springer.com/10.1007/978-3-31928100-1 8-3

12. Long $\mathrm{H}$, Wang $\mathrm{Y}$, Jian $\mathrm{F}$, Liao $\mathrm{LN}$, Yang $\mathrm{X}$, Lai WL. Current advances in orthodontic pain. Int J Oral Sci. 2016;8(2):67-75.

13. Moradinejad M, Jafari $S$, Kazemi $P$, Jafari $F$. Effect of preoperative ibuprofen and acetaminophen on orthodontic pain. World $\mathrm{J}$ Dent. 2016;7(4):182-5.

14. Alqahtani N, Alwakeel A, Alzamil A, Alturki S, Aldawsari G, Aljabaa A, et al. Comparison of two analgesics used for pain relief after placement of orthodontic separators. Saudi Pharm J [Internet]. 2017 Dec;25(8):1169-74. Available from: http://dx.doi.org/10.1016/j.jsps.2017.07.010

15. Patel $S$, McGorray SP, Yezierski R, Fillingim $R$, Logan $\mathrm{H}$, Wheeler TT. Effects of analgesics on orthodontic pain. Am J Orthod Dentofac Orthop [Internet]. 2011;139(1):e53-8. Available from: http://dx.doi.org/10.1016/j.ajodo.2010.07.017

16. Martins IP, Martins RP, Caldas SGFR, dos Santos-Pinto A, Buschang PH, Pretel H. Lowlevel laser therapy $(830 \mathrm{~nm})$ on orthodontic pain: blinded randomized clinical trial. Lasers Med Sci. 2019;34(2):281-6.

17. Mendeley Desktop [Internet]. Elsevier; Available from: https://www.mendeley.com/downloaddesktop-new/

18. Shetty S, Shenoy N, K AS, Unnikrishnan B, Mogra S. Comparison of effects of preoperative piroxicam and ibuprofen on pain after separator placement: A randomized controlled trial. J Orthod Res. 2013;1(2):57.

19. Kohli SS, Kohli VS. Effectiveness of piroxicam and ibuprofen premedication on orthodontic patients' pain experiences A randomized control trial. Angle Orthod. 2011;81(6):1097102.
20. Minor V, Marris CK, McGorray SP, Yezierski R, Fillingim $\mathrm{R}$, Logan $\mathrm{H}$, et al. Effects of preoperative ibuprofen on pain after separator placement. Am J Orthod Dentofac Orthop [Internet]. 2009;136(4):510-7. Available from: http://dx.doi.org/10.1016/j.ajodo.2007.09.018

21. Law SLS, Southard KA, Law AS, Logan HL, Jakobsen JR. An evaluation of preoperative ibuprofen for treatment of pain associated with orthodontic separator placement. Am J Orthod Dentofac Orthop. 2000;118(6):629-35.

22. Sudhakar V, Vinodhini TS, Mathan Mohan A, Srinivasan B, Rajkumar BK. The efficacy of different pre-and post-operative analgesics in the management of pain after orthodontic separator placement: A randomized clinical trial. J Pharm Bioallied Sci. 2014;6(SUPPL. 1):80-5.

23. Stein S, Korbmacher-Steiner H, Popovic N, Braun A. Pain reduced by low-level laser therapy during use of orthodontic separators in early mixed dentition. J Orofac Orthop. 2015;76(5):431-9.

24. Esper MÂLR, Nicolau RA, Arisawa EÂLS. The effect of two phototherapy protocols on pain control in orthodontic procedure-a preliminary clinical study. Lasers Med Sci. $2011 ; 26(5): 657-63$.

25. Kim WT, Bayome M, Park JB, Park JH, Baek $\mathrm{SH}$, Kook YA. Effect of frequent laser irradiation on orthodontic pain a single-blind randomized clinical trial. Angle Orthod. 2013;83(4):611-6.

26. Nóbrega $\mathrm{C}, \mathrm{Da}$ Silva EMK, De MacEdo CR. Low-level laser therapy for treatment of pain associated with orthodontic elastomeric separator placement: A placebo-controlled randomized double-blind clinical trial. Photomed Laser Surg. 2013;31(1):10-6.

27. Nik TH, Shahsavari N, Ghadirian H, Ostad SN. Acetaminophen versus liquefied ibuprofen for control of pain during separation in orthodontic patients: A randomized triple blinded clinical trial. Acta Med Iran. 2016;54(7):418-21.

28. Review Manager (RevMan) [Computer program] [Internet]. The Cochrane Collaboration; 2020. Available from: https://training.cochrane.org/onlinelearning/core-software-cochranereviews/revman/revman-5-download

29. Pancekauskaitè G, Jankauskaitè L. Paediatric Pain Medicine: Pain Differences, Recognition and Coping Acute Procedural Pain in Paediatric Emergency Room. Medicina (B Aires) [Internet]. 2018 Nov 27;54(6):94. Available from: http://www.mdpi.com/1010$660 X / 54 / 6 / 94$

30. Hamblin MR, de Sousa MVP, Agrawal T. Handbook of Low-Level Laser Therapy 
[Internet]. Hamblin MR, Agrawal T, de Sousa $M$, editors. Handbook of Low-Level Laser Therapy. Jenny Stanford; 2016. 35-49 p. Available from: https://www.taylorfrancis.com/books/9789814 669610

31. Bayani S, Rostami S, Ahrari F, Saeedipouya I. A randomized clinical trial comparing the efficacy of bite wafer and low level laser therapy in reducing pain following initial arch wire placement. LASER Ther [Internet]. 2016;25(2):121-9. Available from: https://www.jstage.jst.go.jp/article/islsm/25/2/2 5_16-OR-10/_article

32. Castelnuovo G, Giusti EM, Manzoni GM, Saviola D, Gabrielli S, Lacerenza M, et al. What is the role of the placebo effect for pain relief in neurorehabilitation? Clinical implications from the Italian consensus conference on pain in neurorehabilitation. Front Neurol. 2018;9(MAY).

33. Klinger R, Stuhlreyer J, Schwartz M, Schmitz $J$, Colloca L. Clinical Use of Placebo Effects in Patients With Pain Disorders. Int Rev Neurobiol. 2018;139:107-28.

34. Blasini M, Movsas S, Colloca L. Placebo hypoalgesic effects in pain: Potential applications in dental and orofacial pain management. Physiol Behav. 2018;176(12):139-48.

35. Mazaleuskaya LL, Theken KN, Gong L, Thorn $\mathrm{CF}$, FitzGerald GA, Altman RB, et al. PharmGKB summary: ibuprofen pathways. Pharmacogenet Genomics [Internet]. 2015 Feb;25(2):96-106. Available from: http://journals.Iww.com/01213011201502000-00006

36. Bushra R, Aslam N. An Overview of Clinical Pharmacology of Ibuprofen. Oman Med J [Internet]. 2010 Jul 15;25(3):155-61. Available from: http://omjournal.org/articleDetails.aspx?coTyp $e=2 \&$ ald $=2171$

37. Giannopoulou C, Dudic A, Kiliaridis S. Pain Discomfort and Crevicular Fluid Changes Induced by Orthodontic Elastic Separators in
Children. J Pain. 2006;7(5):367-76.

38. Bruno MB, Bruno MAD, Krymchantowski A V., da Motta AFJ, Mucha JN. A double-blind, randomized clinical trial assessing the effects of a single dose of preemptive antiinflammatory treatment in orthodontic pain. Prog Orthod [Internet]. 2011;12(1):2-7. Available from: http://dx.doi.org/10.1016/j.pio.2011.02.002

39. AlSayed Hasan MMA, Sultan K, Hamadah O. Evaluating low-level laser therapy effect on reducing orthodontic pain using two laser energy values: a split-mouth randomized placebo-controlled trial. Eur $\mathrm{J}$ Orthod. 2018;40(1):23-8.

40. Johal $A$, Ashari $A B$, Alamiri N, Fleming PS, Qureshi U, Cox S, et al. Pain experience in adults undergoing treatment: A longitudinal evaluation. Angle Orthod. 2018;88(3):292-8.

41. Asiry MA, Albarakati SF, Al-Marwan MS, AlShammari RR. Perception of pain and discomfort from elastomeric separators in Saudi adolescents. Saudi Med J. 2014;35(5):504-7.

42. Khan shakeel qutub, Dsouza J, Ashraf B, Talat M. Pain Anticipated \& Pain Experienced During Orthodontic Procedures. Pakistan Oral Dent J. 2017;37(3):434-8.

43. Oshagh M, Najafi HZ, Bahramnia $F$. Comparison of the analgesic effect of lbuprofen and pulsed low - level laser in reducing pain after orthodontic separator placement and evaluation of the changes in the sulcular pain especially prostaglandin E2 level. J Dent Lasers. 2014;8(2):44-9.

44. Freitas PM, Simões A. Lasers in Dentistry: Guide for Clinical Practice. lowa: John Wiley \& Sons; 2015. 230-233 p.

45. Furquim RD, Pascotto RC, Neto JR, Cardoso JR, Ramos AL. Low-level laser therapy effects on pain perception related to the use of orthodontic elastomeric separators. Dental Press J Orthod. 2015;20(3):37-42. 